\begin{tabular}{c} 
Volume and Issues Obtainable at Center for Sustainability Research and Consultancy \\
Journal of Accounting and Finance in Emerging Economies \\
ISSN: 2519-0318 ISSN (E) 2518-8488 \\
Volume 7: Issue 1 March 2021 \\
CSRᄃ \\
Journal homepage: $\underline{\text { www.publishing.globalcsrc.org/jafee }}$ \\
\hline
\end{tabular}

\title{
Human Capital and Endogenous Growth: Incorporating the Role of Unemployment in Determining Returns
}

\author{
${ }^{1}$ Hina Ali, ${ }^{2}$ Saadia Irshad, ${ }^{3}$ Maria Shams Khakwani, ${ }^{4}$ Tayyaba Naveed \\ ${ }^{1}$ Assistant Professor, Department of Economics, The Women University, Multan Pakistan, \\ hinaali@wum.edu.pk \\ ${ }^{2}$ Assistant Professor, Institute of Management Sciences, The Women University, Multan Pakistan \\ ${ }^{3}$ Lecturer, Institute of Management Sciences, The Women University, Multan Pakistan \\ ${ }^{4}$ Lecturer, Department of Psychology, University of Sahiwal, Sahiwal Pakistan

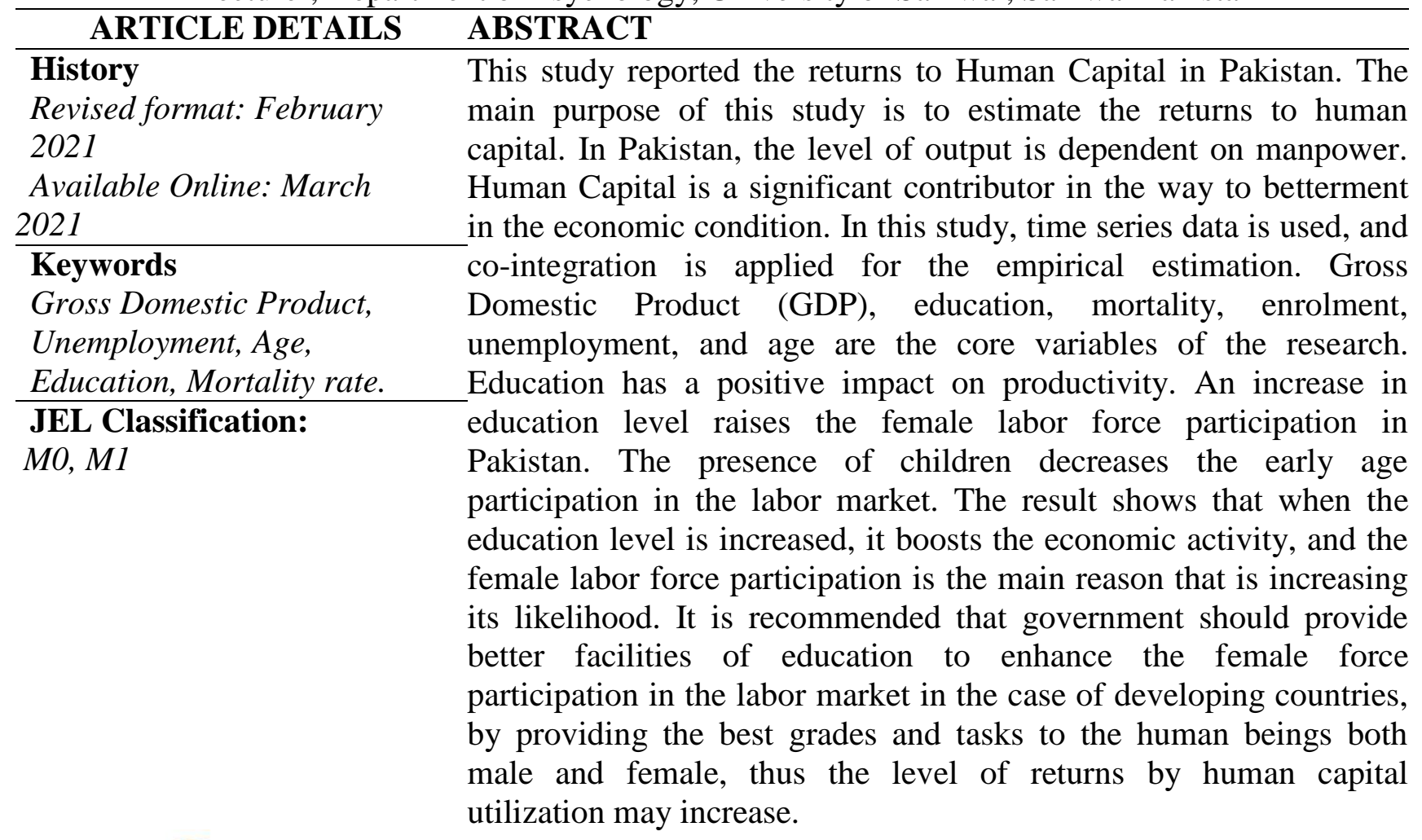

OPEN ACCESS

(C) 2021 The authors, under a Creative Commons AttributionNonCommercial 4.0

Corresponding author's email address: hinaali@wum.edu.pk

Recommended citation: Ali, H., Irshad, S., Khakwani, M. S. \& Naveed, T. (2021). Human Capital and Endogenous Growth: Incorporating the Role of Unemployment in Determining Returns. Journal of Accounting and Finance in Emerging Economies, 7(1), 251-262

\section{Introduction}

Human capital is a subset of possessions and all acquaintance skills, talents, capabilities, experience or information, intelligence and know-how, judgment, training and knowledge, and wisdom controlled on an individual basis (single) and collected by individual persons in a population set. Human capital has a positive impact on economic growth, and it is an important source of Pakistan's labor market and the 
stock of the level of production, skill, and ability. The research also has an assurance that the efforts to increase the productivity get the right results which show that the output by investing in human capital is equally understood by the working ability of the workers (Psacharopulos, 1981). In this study, not only the socio-economic but the human factor is assumed an important factor and is, both directly and indirectly, related to women's contribution in the labor segment (market). One of the studies tests the part of the human capital for every person's earnings in Pakistan and shows the direct and affirmative relationship among the social assets and income. The consequences of the research show that the method of learning and skills of the individual are the two key components of human capital, which has an affirmative outcome on every person's whole life income (Becker, 1962 \& Mincer, 1974).

We know that learning is a major part of an increase in human capital skills. Much of the best quality research done in this field have estimated the output by using the parameter of the increase in wages in different sectors and industries (Psacharopoulos, 1980, 1985, 1994; Pascharopoulos \& Chu Ng, 1994). The result of this observation discovers that a helpful qualitative output for employees in the developing countries is required. Most of the nation-wide typical domestic investigations do not contain the data of the finished years of education, which is essential to approximate Mincer and Becker's production task. The consequences of these explanations discover an obliging quality measure for employees, specifically in developing countries. The limited years of educations completed in Pakistan also ascertain the progressive association between the learning process and wages. We discover that the workers both male and female get high wages as their level of education is going to be higher. The level of income increased with the ever-increasing level of learning. As in the comparison, the wages of the male workers are higher, and the wages of the female workers are lower. The variation amid men and women labor is due to renowned judgments low-paying profession.

\section{Review of Assorted Studies}

Khan and Toor (2003) examined the variations in returns to education in Pakistan. This model studied the variation in marginal rates of return of different levels of education for pay receiving employees and showed that how the specific degree (level) of education varied over the period by the better additional investment. The researcher showed that an increasing return at a different level of education. In this paper, the mean sample and ordinary least square techniques were used for the estimation of the variables. To estimate the variables, the data used was of Pakistan Integrated Household Survey 1990 to 1991 and 2001 to 2002 which was published by the Federal Bureau of Statistics.

Khalid \& Mukhtar (2002) examined the future of girls' education in Pakistan. The secondary data was used in this paper and examined variables were gross enrolment rates, \% of primary teachers by gender, literacy rate, productivity growth, female and male labor force. They focused on the increase in the literacy rate of developing countries, and they pay more attention to achieve education for all. Pakistan was also part of this developmental framework. In conclusion, this study supported that in the future, the countries should pay attention to the girls' education which increased the importance of the girls and the $\%$ in literacy also increased by the efforts of institutions.

Nasir (2005) performed the analysis of occupational choice in Pakistan. In the determination of earning and success in the labor market, occupational choice plays an important role. Men and women had different occupational distribution; this was the main discussion in this regard. The model of men and women occupational choices were estimated by utilizing the 'Pakistan Integrated Household Survey' (PIHS) 2001-2002 data. They had taken variables discussed in this model were men and women salaries, the labor force in the market, skills, productivity of men and female workers, wages, and literacy. The econometric technique Multinomial Logit (MNL) is used in this paper. The conclusion of this analysis showed that the positive outcome on the earning of the workers.

Faridi, Malik \& Basit (2009) explored an analysis about the educations of male participation in the labor 
force and status of employment in Pakistan (Bahawalpur District). Time series data was used for this estimation. Econometric techniques Binomial Logit and Multi-nomial Logit were approached for this analysis. They investigated the participation of the labor force and status of employment varied with age specification, education level, residence region, closed relative's education level, and gender via examining statistical tools and techniques. Findings assured that the different levels of education, asset presence, the burden of dependent persons, and residence (location) were affecting participation in different employment statuses significantly.

Faridi et al. (2009) explored the effect of education on women's participation in the labor force in Pakistan's economy. Time series data was used for this estimation. Econometric technique Binomial Logit and Multi-nomial Logit approached for this analysis. The effect of parent's education was insignificant while the role of education status of the spouse had assured affirmative and significant effect on labor force participation of females. Thus, the research concluded that the education of females was successfully significant in attaining higher employment levels, extending growth and output.

Faridi et al. (2010) explored the education affiliation with students' earnings in public sector universities in Pakistan. Time series data was used for this estimation. Econometric technique OLS (Ordinary Least Square) was examined to check the effect of education level on student learning level. Results showed that completed years of education and experience in years are positively and significantly contributing to the monthly earnings of students in the first model. At the education level, the monthly earnings of students are increasing and have a significant impact on the earnings of students. Study shows that PhD and M.Phil. students can earn more than bachelor students. This indicated an affirmative correlation of education level with earning level. Several worked hours and experience also show the affirmative correlation in different monthly earnings levels.

Chaudhry, Faridi \& Anjum (2010) observed the effect of health and education on female earnings. The measures of human capital, health and education are considered most significant. The main goal of this research was to find out the effects of health and education on the wages of female workers in Pakistan. The technique used in this model were descriptive and OLS. Health and education have a significant and positive impact on earnings of the female workers. The variables used in the study were education, health status, mortality rate, age, and training.

Son (2010) deeply explored human capital development. This paper has two main goals. Firstly, it worked on measuring the gaps in the human capital stock across the world. It showed that how effectively many countries were moving towards the development path by the improvement in human capital stock. Secondly, it worked on the contribution of the human capital for economic growth and worked for the employment growth, which also affects the human capital growth to explain the total output per workers' growth. They had taken variables for literacy rate, school enrolment rates, years of schooling, education skills, workforce, gender disparity, total output, and Gross Domestic Product (GDP). The world's poorer areas like South Asia and Sub-Saharan Africa have incredibly low human capital in early 1950.

Nasir and Nazil (2010) worked on the education and earnings in Pakistan and returns to human capital. The theory of Human Capital was conventionally developed by Becker (1962) and Mincer (1974). To estimate all variables, the dummy variable technique was used in this model. The variables used in this model were completed years of schooling, age starting school, literacy, numeracy skills, quality of the school, and technical training. Most of the nationally representative surveys of households do not contain information about the variables like quality of the school, literacy, age starting school, numeracy skills, quality of the school, completed years of schooling, etc. The Pakistan Integrated Household Survey (PIHS) worked on these variables to provide all the available data regarded to these above listed variables. 
Himaz \& Aturupane (2011) examined the education and household welfare in a case study of Sri-lanka. They used cross-section during the period 1985 to 2006. The econometric techniques OLS and QR were used. In this paper, two main findings came out from this analysis. The results showed that individual qualifications were important in the labor market and another result related to the upper qualities collision shows the privileged force of education on welfare than lower qualities, the representative that these households are superior to their human capital welfare.

Ali (2011) worked on education reforms undertaken in Sindh, Pakistan by exploring the Deficient Policy Communication and Deficient Outcomes-Capacity Building Policy. In 2003, USAID sponsored the program "Education Sector Reforms Assistance" (ESRA) to build the capacity of District Education Managers. The method of qualitative research was used to drive up the work for more effective results. Most of the policies failed to achieve any of the arranged targets year after year despite the special management. The result of this model was to understand the capacity-building policy of education managers in Pakistan.

Khadim and Akram in 2013 investigated female labor force participation in the formal sector. Econometric techniques such as Binomial Logit and Multi-nomial Logit are approached for this analysis. The empirical results of the study suggest that for women higher education attainments lead to greater participation in the formal sector. Their results elucidate that there is a greater probability of female labor force participation with education at primary and matriculation level and the females are more likely to participate are married and belong to a nuclear family living in an urban area.

Afzal (2014) looked at the analysis of the earning-oriented education system of Lahore, Pakistan. The study describes the effect of the factors that affect the earnings and estimates the returns to the education of the educational institutes in Lahore. They used the primary data for a sample of 8327 respondents in 2011 and the econometric technique of ordinary least square (OLS) in this study. They had taken variables of computer skills, literacy rate, earning of individuals, nature of the job, family background, marital status, gender, and training. The theory of Human Capital was valid in this regard. The final suggestion of this paper showed that education has a positive impact on the future life of individuals.

Mat, Mansur \& Mahmud (2015) discussed the impact of human capital investment on education and economic development in the case of Sabah. The econometric technique ordinary least square (OLS) was used in this paper. The annual period of 1980 to 2010 was used and the Solow growth model theory was applied in framework development. Gross domestic product (GDP) per capita was used as a dependent variable and literacy rate, life expectancy at birth, several immigrations, and growth rate of capita were used as independent variables. The result shows that human capital on education boosts the literacy rate concerning additional schooling.

Jamal (2015) worked on private return to education, a case study in Pakistan. He used the period of 1990 to 2013. The data was composed of 16 nationally labor force surveys through this period, that were utilized with some revision. In this study traditional approach LFC was used. The source of data was the Pakistan Bureau of Statistics (PBS).

Qadir and Afzal (2019) examined the effect of male and female health in economic growth, crosscountry evidence within a production function framework. Human capital plays a significant role in economic growth. The major purpose of the paper was to show that the life expectancy of the male has a positive effect on the economic growth and the life expectancy of females has a negative impact. They had taken variables for life expectancy, age, health rate, capital stock, economic growth, and GDP. The techniques used were OLS, random effect, and three stage least squares estimation. 
Mushtaq, Hussain, Afzal \& Gilani (2020) discussed the impact of the education labor force on the economic growth of Pakistan. The time series data was used in the time period of 1973-2013. The techniques used in this model were the Vector Auto Regressive test (VAR) and the Johansen Cointegrated test. The variables of the labor force, physical capital, illiterate labor and real GDP were examined in the study. The findings of this study showed that human capital has a positive contribution to economic growth. The research showed that investments in human capital can increase productivity growth at the macro level.

Uduji, J. I., Okolo-Obasi, E. N., \& Asongu, S. A. (2020) elaborated the investment activities that promote human capital growth over the years in Nigeria for both the private and public levels. The explicit education investments at the individual level to macroeconomic financial allocations for education development. Also, the administration has to come up along with the program that is reliable along with global initiatives to promoting schooling for all, like the Millennium Growth Goal (MDG) 4 upon Universal Primary Schooling as well as the Sustainable Growth Goal aims at confirming equitable and inclusive quality schooling and indorsing enduring learning prospects.

Adejumo, O. O., Asongu, S. A., \& Adejumo, A. V. (2021) examined the vibrant interrelationship amongst school enrolment and rate of employment. The study employed ARDL and VAR model to analyze these relations. It was stated that more investment in human capital, concluded education, especially at upper levels, permits human capital to progress with dynamism and increase growth. It led to education-driven growth that facilitates employment. Consequently, investments in schooling identified as a dynamic channel for the construction of human capital and achieving long run development. Therefore, sustainable development, demonstrated by the educational-driven growth, will also lower unemployment.

\section{Model Specification, Data, and Methodology}

This section justifies the data and methodology of this study. Time variant data has been examined for analysis. To analyze the association amid selected variables, data from 1976-2019 had been taken. The data is collected from the State Bank of Pakistan and the IMF. The econometric technique of AutoRegressive Distribution Lag (ARDL) established by Pesaran and Shin (1999) and Pesaran, Shin \& Smith (2001) is used in this study. The unit root test of Augmented Dickey-Fuller (ADF) has been used to confirm the stationarity of parameters.

The present study has been specified in following model:

$Y=\alpha+\beta 1 X_{1}+\beta 2 X_{2}+\beta 3 X_{3}+\beta 4 X_{4}+\beta 5 X_{5}+\mu$

$\mathrm{Y}=$ Gross Domestic Product (GDP)

$\mathrm{X} 1=$ Education

$\mathrm{X} 2=$ Mortality

$\mathrm{X} 3$ = Unemployment

$\mathrm{X} 4=$ Age

$\mathrm{X} 5$ = Enrolment

Now, these variables are justified in the ARDL estimation equation. In this equation $\mathrm{Y}$ is denoted by the dependent variable that is affected by $X$ and by their own lagged values. $X$ shows the independent variables. These variables have different relationships; some are positive and some negative. The consistency of 'ARDL' has been skilled through examination of this research. Analysis strength and vigor has been checked by intaking the sequential correlation, functional form, heteroskedasticity test, and normality distribution. Moreover, CUSUM and CUSUM SQUARE constancy is another form to decide the stability and consistency of the ARDL. 


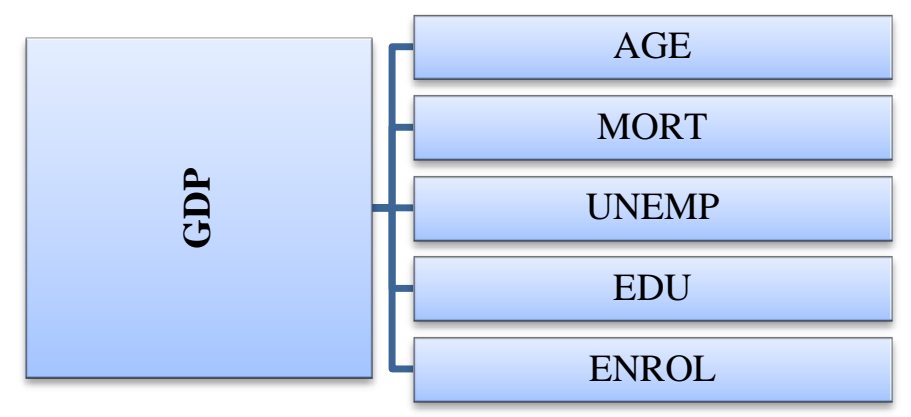

Figure 1: Conceptual Framework of dependent and independent variables

There is Gross Domestic Product as dependent variable representing growth and education, mortality, unemployment, age, and enrolment are independent variables.

\section{Description of Variables}

\subsection{Gross Domestic Product}

GDP (Gross Domestic Product) is one of the most usually used measures of an economy's output. It is defined as the "total value of goods and services produced within a country's margins in specific time period-monthly and yearly". GDP is a correct sign of the size of the economy.

\subsection{Education}

Education reflects an individual's ability to read and write. Education has a positive effect on one's life. In Pakistan, many people are well educated. People get the education primary and secondary system. In Pakistan, $44 \%$ of people are educated. In urban areas, women get an education in colleges and universities. In rural areas, women are getting less education because they worked the field with men.

\subsection{Mortality Rate}

The mortality rate is defined as the unit of death per 1000 people per year. $9.5 \%$ mortality rate of the whole population. Many diseases, for example, cancer, TB, and aids spread in our country. Many people are dying from a lack of food and issue of health facilities. In Pakistan, the death rate increases day by day.

\subsection{Unemployment Rate}

The unemployment rate is the percentage of total persons unemployed to the total labor force. The unemployed person is one that started their search to get a job but cannot get any job. In our economy many people are unemployed. Some people go to abroad and send the earned money to their families. In our country, the jobs are few and people face unemployment. In Pakistan as compared to developed countries, more people are jobless. Here mostly peoples are un-skilled and do not work properly.

\subsection{Employment}

People have employment means that they are being paid for their full / part time job and works. Many people do work; it may be a part time job, or a full-time job and some people spend their time in their family business. They are referred to as an employed person. People seek the training programs to get better job opportunities and it may enhance their working capability and may cause a decline in chances of job loss or separation from a family business.

\subsection{Enrolment}

Matriculation, the process of getting registration/admission to any college or university. Enrolment 
implies the total number of students appropriately registered. The method of being entered onto an electoral roll. Concurrent enrolment, the procedure in which a high school student enrolls at a university or college typically to achieve college praise. Biometrics, the procedure of adding a user credential to the verification system.

These variables are listed in table 1, along with their expected direction of association with the dependent variable, GDP.

Table 1: Variable's Description

\begin{tabular}{|l|l|l|}
\hline Variables & $\begin{array}{l}\text { Descriptive } \\
\text { Variables }\end{array}$ & Expected Sign \\
\hline GDP & Gross Domestic Product & Positive \\
\hline Edu & Education & Positive \\
\hline Age & Age & Positive \\
\hline Mort & Mortality & Negative \\
\hline Unemp & Unemployment & Negative \\
\hline Enrol & Enrolment & Positive \\
\hline
\end{tabular}

\section{Analysis and Discussion}

The table 2 shows the analysis of selected variables which are GDP, Edu, Mort, unemployment, age, and Enrol. We show the values of mean, median, skewness, kurtosis and jarque-bera. The p-values of jarquebera estimates for all variables are greater than 0.05 , thus signifying the normality of the distribution.

Table 2: Descriptive Analysis

\begin{tabular}{|l|l|l|l|l|l|l|}
\hline Variables & Mean & Median & Std.Dev & Skewness & Kurtorsis & $\begin{array}{l}\text { Jarque } \\
\text { Bera }\end{array}$ \\
\hline GDP & 5.123 & 5.5 & 2.291 & -0.618 & 3.266 & 2.599 \\
\hline Edu & 1.785 & 1.800 & 0.336 & 0.387 & 2.011 & 2.692 \\
\hline Mort & 128.3707 & 128.300 & 28.168 & 0.0216 & 1.680 & 2.979 \\
\hline Unemp & 9.772 & 9.600 & 4.731 & 0.528 & 2.476 & 2.371 \\
\hline Age & 35.104 & 35.900 & 4.671 & -0.011 & 1.334 & 4.744 \\
\hline Enrol & 68.022 & 70.688 & 15.390 & 0.295 & 1.788 & 3.103 \\
\hline
\end{tabular}

Table 3: ADF Test Results with Level and $1^{\text {st }}$ Difference

\begin{tabular}{|l|l|l|l|l|l|l|}
\hline \multicolumn{2}{|l}{ Variables } & \multicolumn{2}{l|}{ ADF test } & \multicolumn{2}{c|}{ Result } \\
\hline & \multicolumn{2}{|c|}{ Level } & \multicolumn{1}{l|}{$\mathbf{1}^{\text {st }}$ difference } & \\
\hline GDP & 1.950686 & 0.131592 & Intercept & Trend & \\
\hline Edu & -1.924679 & -1.071376 & $-4.778045^{* * *}$ & $-5.229734^{* * *}$ & $\mathrm{I}(1)$ \\
\hline Mort & $1.328003^{* * *}$ & $-5.834085^{* * *}$ & $-3.729400^{* * *}$ & $-4.883165^{* * *}$ & $\mathrm{I}(1)$ \\
\hline Unemp & -1.633038 & -1.669866 & $-10.27427 * * *$ & -3.903278 & $\mathrm{I}(0)$ \\
\hline Age & 4.888981 & 4.550720 & $-5.673092^{* * *}$ & $1.3573973^{* * * *}$ & $\mathrm{I}(1)$ \\
\hline Enrol & -0.004240 & -2.613707 & $-6.383087 * * *$ & $-6.404868^{* * *}$ & $\mathrm{I}(1)$ \\
\hline
\end{tabular}

(Note $*, * *, * * *$ indicator of the significant level at $10 \%, 5 \%, 1 \%$ respectively).

In the 'ADF' test we confirm the stationary of data set in time series analysis. Mortality variable is the only one that is stationary at level; however, rest of the other variables are not stationary at level but stationary on first difference. When some of the variables have $1^{\text {st }}$ difference stationarity and some have at the level then we will apply ARDL. After using the ARDL technique in this study, in the following table 4, some results about bounds test for cointegration (long term relation) between the variables are provided below. 
Table 4: ARDL Bound Test Results

\begin{tabular}{|c|c|c|c|}
\hline Equation & F-Statistic & $\begin{array}{l}\text { Bound Value } \\
\text { at } 5 \%\end{array}$ & Results \\
\hline $\begin{array}{l}\text { F GDP (GDPLEdu, Mort, Unemp, Age, } \\
\text { Enrol) }\end{array}$ & $6.277 * * *$ & $\begin{array}{ll}3.38 & \text { Upper } \\
2.39 & \text { Lower }\end{array}$ & $\begin{array}{l}\text { Co-integration } \\
\text { exists }\end{array}$ \\
\hline
\end{tabular}

(Note $*, * *, * * *$ indicator the significant at $10 \%, 5 \%, 1 \%$ respectively).

In the preceding Bound test, we illustrate the F-statistics value of the model. This value which is greater than all upper bound values when $\mathrm{k}$ is 5 , leading to the interpretation that when $\mathrm{F}$ value is more than upper bound, it ensures cointegration and when it is below the lower bound, it shows no possibility of cointegration. In case when $\mathrm{F}$ value is between lower and upper bounds (whose values have been established by Pesaran et al. in 2001 at different significant levels), it gives inconclusive evidence of cointegration. Hence results show co-integration in the long-run relationship.

Table 5: Estimates of Long- Run Co-efficient of Model

\begin{tabular}{|l|l|l|l|}
\hline Variables & Coefficient & t-statistics & Prob \\
\hline EDU & 15.271104 & 5.282209 & 0.079 \\
\hline AGE & 42.306430 & 6.084003 & 0.000 \\
\hline ENROLL & 4.3606430 & 1.027491 & 0.003 \\
\hline UNEMP & -1.340513 & -0.384445 & 0.036 \\
\hline MORT & -6.442325 & -3.896750 & 0.000 \\
\hline C & -903.08208 & -1.979736 & 0.057 \\
\hline
\end{tabular}

In this table 5, mortality and unemployment showed a negative association with Gross Domestic Product, while education, enrolment and age have a positive association with gross domestic product. The co-efficient values explain the effects of different variables on Gross Domestic Product in the long run. The effect of variables when the probability less than 0.05 then it will be significant while the probability is greater than 0.05 then it will be insignificant.

In the table 6, the detailed effect of variations in dependent variable due to independent, or in other words the coefficients of short term association between them, are presented.

Table 6: Estimates of Short-Run Co-efficient of the Model

\begin{tabular}{|l|l|l|l|}
\hline Variables & Coefficient & t-Statistics & Prob \\
\hline $\mathrm{D}(\mathrm{GDP}(-1)$ & 0.278931 & 2.488777 & 0.0190 \\
\hline $\mathrm{D}(\mathrm{EDU})$ & 70.36982 & 1.961250 & 0.0399 \\
\hline $\mathrm{D}(\mathrm{EDU})$ & 12.62426 & 2.830083 & 0.0085 \\
\hline $\mathrm{D}(\mathrm{AGE}(-1)$ & 20.3534 & 4.453833 & 0.0001 \\
\hline $\mathrm{D}(\mathrm{ENROL})$ & 1.076335 & 0.505044 & 0.6175 \\
\hline $\mathrm{D}(\mathrm{UNEMP})$ & -0.54416 & -0.372280 & 0.0125 \\
\hline $\mathrm{D}($ MORT $)$ & -2.84660 & -1.082225 & 0.2884 \\
\hline
\end{tabular}




\begin{tabular}{|l|l|l|l|}
\hline CoinEq (-1) & $\mathbf{- 0 . 4 9 1 4 2 2}$ & -6.371952 & 0.0000 \\
\hline R-Squared & 0.9736 & AIC 1.0852 & \\
\hline Adjusted R-squared & 0.9736 & SC 1.8890 & \\
\hline F-statistic & 18.5721 & & \\
\hline Prob (F-ststistic) & 0.0000 & HQ 1.3615 & \\
\hline Durbin-Watson & 2.104414 & & \\
\hline
\end{tabular}

The coefficient of Gross Domestic Product (GDP (-1)), EDU and ENROL show the positive relationship, while UNEMP and MORT show the negative relationship in the short run. In the above table, effect of the variables has been examined to testify probability values of the estimates. If the probability is lower than " 0.05 " then; it'll be statistically significant while if the probability value is higher than "0.05" then it'll be insignificant statistically. Table 6 also provides the value of error correction term (ECT) labelled as CoinEq (-1). Its value must be negative and significant. Both conditions are fulfilled in this model. Value of ECT indicates the adjustment speed towards equilibrium in short term and here results exhibit that almost $49 \%$ of the disequilibrium among the variables will be adjusted by the next period i.e., in the shoer run.

\subsection{Stability Test}

In ARDL model, the stability test should be defined as CUSUM and CUSUM of Square test.

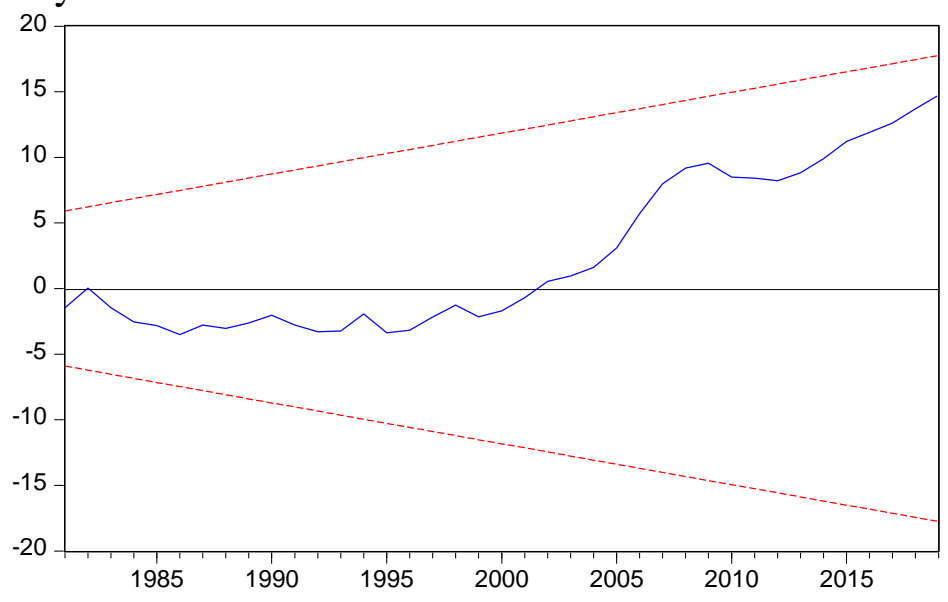

This diagram exhibits the CUSUM analysis ranges amid the 'Red bars' which are the critical region; lies at the $5 \%$ significant level that's why this exhibits that the model is significant and accurate. This figure exhibit that the examined model is accurately and precisely accounted for.

\subsection{CUSUM of Square Test}

In this diagram, short run and long run are checked by CUSUM of the square test. 


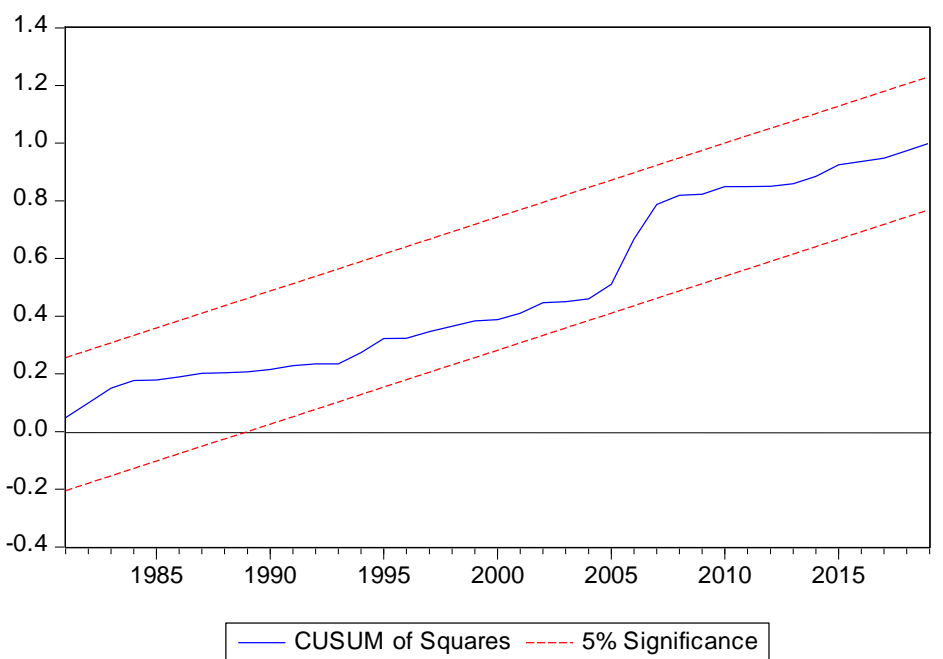

CUSUM-Square ranges amid the 'Red bars' that are the critical regions; lies at the $5 \%$ significant level that's why this exhibits that the model is significant and accurate. This figure exhibit examined model manages range and precisely accounted.

\section{Conclusion and Policy Implication}

The research identified the major determinates of human capital like Gross Domestic Product, Education, Age, Mortality, Unemployment, and Enrolment. For this purpose, we use time series data which covered 1976 to 2019, and the source of data is State Bank of Pakistan. It used the ARDL model for cointegration analysis and for testing the presence of association among variables in short and long term. The total population of Pakistan plays an important role in our country's economic growth. The participation of workers in the labor market is increasing due to their increasing rate of literacy. Education is particularly important for our economy and it positively affects participation of workforce, reduces unemployment and enhances the returns to human capital. According to the findings of this research, less mortality has more chances of jobs; hence, decline in unemployment in the labor market. In this study, age has been shown among positive factors for economic growth. A low level of education has shown negative effects on economic activities.

In this study, human capital has a positive effect on the economy. The GDP will increase if we utilize the resources positively and for productivity. Education can increase the GDP of our country; provided there are policymakers creating appropriate opportunities for the educated youth to get employed in economy, thus adding more value to the economic development and prosperity. The rate of mortality can be reduced if the government realizes the critical importance of health sector and allots substantial extent of budget to it so that improved health services would be made available for the overall population. Government should improve the facilities of education for the masses of the economy. It can be done by improving the education system, by providing training and setting up more professional schools. The policymakers may well adopt policies to enhance investment in education as a way of human capital, thereby ultimately leading to sustainable economic growth.

\section{References}

Adejumo, O. O., Asongu, S. A., \& Adejumo, A. V. (2021). Education enrolment rate vs employment rate: Implications for sustainable human capital development in Nigeria. International Journal of Educational Development, 83, 102385.

Afzal, M. (2014). Micro econometric Analysis of earnings-oriented educational system of Lahore (Pakistan). Pakistan Economic and Social Review, 52(2), 227.

Ali, S. (2011). Deficient policy communication deficient outcomes-capacity building policy under education reforms in Sindh, Pakistan. Bulletin of Education and Research, 33(1), 1.

Becker, G. S. (1962). Investment in human capital: A theoretical analysis. Journal of political economy, 70(5, Part 2), 9-49. 
Chaudhry, I. S., Faridi, M. Z., \&Anjum, S. (2010). The Effects of Health and Education on Female Earnings: Empirical Evidence from District Vehari. Pakistan Journal of Social Sciences (PJSS), 30(1).

Faridi, M. Z., Chaudhry, I. S., \& Basit, A. B. (2009). An Analysis of the Determinants of Male Labor Force Participation and Employment Status in Pakistan: The Case of Bahawalpur District. Pakistan Journal of Social Sciences (PJSS), 29(2).

Faridi, M. Z., Malik, S., \&Basit, A. B. (2009). Impact of Education on Female Labor Force Participation in Pakistan: Empirical Evidence from Primary Data Analysis. Pakistan Journal of Social Sciences (PJSS), 29(1).

Faridi, M. Z., Hussain, S., \& Bashir, F. (2010). Impact of Education on Students Earnings: A Case of Public Sector Universities in Pakistan. International Research Journal of Finance and Economics, 42, 171-178.

Khan, F. S., \& Toor, I. A. (2003). Changes in returns to education in Pakistan: 1990-2002.

Hassan, G., \& Cooray, A. (2012). The effect of female and male health on economic growth: crosscountry evidence within a production function framework.

Himaz, R., \& Aturupane, H. (2011). Education and Household Welfare in Sri Lanka from 1985 to 2006. Department of Economics, University of Oxford.

Jamal, H. (2015). Private Returns to Education in Pakistan: A Statistical Investigation.

Khadim, Z., \& Akram, W. (2013). Female labor force participation in the formal sector: An empirical evidence from PSLM (2007-08). Middle-East Journal of Scientific Research, 14(11), 1480-1488.

Khalid, H. S., \& Mukhtar, E. M. (2002). The future of girls' education in Pakistan. Islambad: UNESCO Offfice.

Khan, F. S., \&Toor, I. A. (2003). Changes in Returns to Education in Pakistan: 1990-2002.

Mat, N. A., Mansur, K., \& Mahmud, R. (2015). The relationship between human capital investment and economic development in Sabah. Malaysian Journal of Business and Economics (MJBE), 2(1).

Mincer, J. A. (1974). Introduction to" Schooling, Experience, and Earnings". In Schooling, experience, and earnings (pp. 1-4). NBER.

Mushtaq, K., Hussain, M., Afzal, M., \& Gilani, S. A. (2020). Health Care Delivery System of Pakistan and Bangladesh: A Comparative Analysis. National Journal of Health Sciences, 5(1), 35-41.

Nasir, Z, M. \& Nazli, H. (2010). Education and earnings in Pakistan. Working papers \& Research Reports; RR-NO.

Nasir, Z. M. (2002). Returns to human capital in Pakistan: A gender disaggregated analysis. The Pakistan Development Review, 1-28.

Nasir, Z. M. (2005). An analysis of occupational choice in Pakistan: A multinomial approach. The Pakistan Development Review, 57-79.

Pesaran, M. H., Shin, Y., \& Smith, R. P. (1999). Pooled mean group estimation of dynamic heterogeneous panels. Journal of the American statistical Association, 94(446), 621-634.

Pesaran, M. H., Shin, Y., \& Smith, R. J. (2001). Bounds testing approaches to the analysis of level relationships. Journal of applied econometrics, 16(3), 289-326.

Psacharopoulos, G. (1980). Higher education in developing countries. World Bank staff working paper, (440).

Psacharopoulos, G. (1981). Returns to education: an updated international comparison. Comparative education, 17(3), 321-341.

Psacharopoulos, G. (1985). Returns to education: a further international update and implications. Journal of Human resources, 583-604.

Psacharopoulos, G. (1994). Returns to investment in education: A global update. World development, 22(9), 1325-1343.

Psacharopoulos, G., \& Chu Ng, Y. (1994). Earnings and education in Latin America. Education Economics, 2(2), 187-207.

Qadir, F., \& Afzal, M. (2019). Impact of Cultural Factors on Earnings of Working Women in Khyber Pakhtunkhwa, Pakistan. European Online Journal of Natural and Social Sciences: 
Proceedings, 8(1 (s)), pp-92.

Son, H. H. (2010). Human capital development. Asian Development Bank Economics Working Paper Series, (225).

Uduji, J. I., Okolo-Obasi, E. N., \& Asongu, S. A. (2020). The impact of corporate social responsibility interventions on female education development in the rural Niger Delta region of Nigeria. Progress in Development Studies, 20(1), 45-64. 